DOI: $10.17951 / \operatorname{lrp} .2021 .40 .2 .37-52$

\author{
Anna Gagat-MatuŁa
}

Uniwersytet Pedagogiczny im. KEN w Krakowie

ORCID - 0000-0002-9349-5924

\title{
SOCIAL SUPPORT IN THE PERCEPTION OF MOTHERS OF CHILDREN WITH AUTISM SPECTRUM DISORDERS EXPERIENCING THEIR HUSBAND'S MIGRATION
}

\begin{abstract}
Introduction: A woman whose husband migrates faces an everyday struggle in raising a child with autism spectrum disorders. Hence, it is important that a woman receive social support in stressful situations, such as raising a disabled child and experiencing her husband's migration. Research Aim: The study aim was to determine social support in the perception of mothers of children with autism spectrum disorders experiencing their husband's economic migration. An important goal was also to show the differences between perceived social support among mothers of children with autism experiencing their husband's migration, and those whose husbands do not migrate. Method: The research used the diagnostic survey method with the following tools: Ewa Szlachta's Polish adaptation of the ISEL questionnaire and a self-made questionnaire. The research involved 94 mothers raising children with autism: 46 women whose husbands migrate (A) and 48 women who husbands did not migrate (B). The sample selection was deliberate. Results: Data analysis showed statistically significant differences between the groups, both for the overall result and all scales. The results indicate that while mothers of children with autism whose husbands go abroad experience better financial conditions, the absence and lack of active participation and support of the husband in caring for the child makes them perceive less social support (scale of cognitive support, belonging, self-esteem), and they cope with problems much worse than women whose husbands do not go abroad. Conclusions: The obtained research results indicate the need for preventive action.
\end{abstract}

Keywords: autism spectrum disorder, migration, mother, social support

\section{INTRODUCTION}

The diagnosis of a child's disability is often a turning point in the life of every family. In addition to numerous typical parental responsibilities related to raising a child, 
there are a number of additional tasks and challenges related to the functioning of a child with a disability (Breitkreuz et al., 2014; Tøssebro, Wendelborg, 2015). Many studies mention a number of factors that make parents of autistic children extremely vulnerable to stress. These factors include, but are not limited to:

- late diagnosis and problems in obtaining it;

- feeling a lack of emotional connection with the child, especially clear signs of attachment and the showing affection on the child's part;

- difficulties in communicating with the child, resulting from disorders typical of autism in the sphere of verbal and non-verbal communication (facial expressions, gestures);

- the unusual, unpredictable course of a child's development - from relatively normal to retention, regression and then to delayed;

- uneven development and paradoxes in functioning leading to the child's behaviour being difficult to predict even in ordinary situations, but at the same time, thanks to good functioning in certain spheres, an appearance of normality is created making expectations towards the child grow;

- the "does not want to" or "cannot" dilemma regarding parents' uncertainty about the child's abilities;

- normal appearance, making it difficult to understand the degree and nature of the developmental problems;

- bizarre incomprehensible behaviour, hyperactivity, stereotypes, self-aggression, difficult behaviour in public places;

- frequent co-occurring intellectual disability;

- lack of a support system, lack of understanding of the problem by those in the environment, ignorance of specialists who propose various, often ineffective methods;

- poor prognosis and limited recovery (Pisula, 1998).

Particularly stressful for parents is the development of a child on the spectrum of autism disorders, as it also causes stress for the parents due to its unpredictability. This may correct itself in some spheres, while in some it is halted or regressed, and in others there is a long delay, with this all contributing to problems with predicting the child's behaviour, even in everyday life. The correctness of development in some areas increases the parents' expectations, while the lack of stability in its development contributes to the inability to create a coherent image of the child and the inability to assess the child's abilities. The normal appearance of the child is also a source of difficulties for parents in understanding what the child's developmental problems are and the scale of such problems, and is also associated with parents receiving severe criticism from those in their environment about how they are raising the child. There is also the heavy burden of behaviours 
that are difficult to understand, such as screaming, rocking, rolling the fingers in front of the eyes etc., as well as stereotypes, hyperactivity and self-aggression, which increase in intensity in public places. Another problem that causes stress is the lack of understanding of the problem by those in the environment, the lack of knowledge of specialists, the lack of a support system for children with autism and their families, and great loneliness (Pisula, 1991). Research by Baker-Ericzen et al. (2005), Sekułowicz (2013), Dąbrowska, Pisula (2010); Banasiak (2013), Bitsika et al. (2013); Shobana, Saravanan (2014), Bonis (2016), and Padden, James (2017) show that parents of children with autism spectrum disorders are in a particularly difficult situation. The level of parental stress they experience is higher in mothers than in fathers, and also, importantly, higher not only in comparison to parents of children with normal development, but also in comparison to parents of children with other developmental disorders. Research by Rivard et al. (2014) indicates that fathers of children with autism spectrum disorders reported higher levels of stress than mothers. The stress levels of both parents of children with autism spectrum disorders were associated with their child's age, intellectual quotient, severity of autistic symptoms, and adaptive behaviors. Paternal stress, but not maternal stress, was predicted by the severity of the autistic symptoms and the child's gender. In the case of women, high levels of stress and the long-term care of a child with autism spectrum disorders resulted in loosening of relationships with friends, with this leading to a feeling of maternal loneliness (Farrugia, 2009).

Additionally, problems multiply when a family with a disabled child migrates or when one of the parents migrates.

On the one hand, the father's economic migration brings economic benefits to both the migrant and the individual members of his family. These benefits result from the higher income that can be obtained abroad compared to the income available at home. The improvement of a family's material situation thanks to economic migration is conducive to an increase in consumption and household savings/investment. This has a positive impact on the current and future functioning of such families. In addition, income transferred to families in the form of remittances increases the number of bank accounts, and thus increases the level of financial inclusion, which is important for the functioning of the household and reduces the risk of social exclusion. Increased family incomes improve living conditions, mainly in terms of family nutrition, sanitation and healthcare. Thus, the standard of living of such families is raised. For families of children with disabilities, additional income abroad increases access to therapy and can ensure its continuity. In the case of children with autism spectrum disorders, a parent's economic migration increases the chances of them having access to extremely effective, but unfortunately expensive, intensive early 
behavioural therapies or other therapies important for the child's development (UNICEF, 2020).

On the other hand, the absence of one parent as an important caregiver may decrease the likelihood of the child making progress in therapy. The effectiveness of the family's influence on the child's progress rises with an increase in the number of relatives involved in the rehabilitation process. Parents, both mother and father, play a particularly significant role in this (Chodkowska, 2007). The temporary absence of one of the parents limits the proper functioning and proper organization of the family, and causes disruption to the family's structure (Fojcik, 2007; Szymborski, Potrykowska, 2009). Such a situation may negatively affect both the relationship between the spouses and the development of the children, especially those who require special care. The results of sociodemographic research confirm that international migration may result in an increase in divorce (Caarls, Mazzucato, 2015). A woman whose husband goes abroad for work is overburdened, not only with diagnosis and rehabilitation, but also with the everyday struggle related to raising a child. A woman needs a partner, a close person with whom she can make decisions together and share tasks related to the care of a disabled child. It is the husband as the closest person who knows best how to console his partner and help her in difficult situations (Gagat-Matuła, 2018). Hence, social support plays an important role among the factors that contribute to coping. Research by Feldman et al. 2002 and Luther 2005 indicates a relationship between high social support and lower levels of stress associated with caring for a disabled child. Research has suggested that informal support, such as that provided by partners, friends and family may be particularly beneficial in promoting maternal well-being in this population (Boyd, 2002). Research by Ekas et al., 2010 showed that social support provided by a partner, other family members and friends was associated with lower levels of depression, negative affect and parental stress in mothers of children with autism spectrum disorder. With regard to positive maternal outcomes, social support received from friends was associated with increased life satisfaction, positive affect and psychological well-being, whereas partner support was associated with increased life satisfaction and psychological well-being. Finally, social support received from other family members was associated only with increased psychological well-being.

Hence, it is extremely important that a woman receive social support in situations of permanent stress, such as raising a child with autism spectrum disorders and experiencing a temporary separation from her husband due to foreign migration.

In the psychology of health, social support, apart from the sense of coherence, is the most frequently mentioned factor determining the quick recovery of an individual (Kirenko, Byra, 2008). People experience social support in everyday 
life in their relationships and interactions with other people, and the demand for such support increases in crisis situations (Sęk, 1997).

According to Helena Sęk (2001), the term 'social support' is still ambiguous and has a variety of definitions. Attempts have been made to distinguish certain categories of social support and to specify them. One of the possible approaches to social support is the distinction between functional and structural support (Sęk, Cieślak, 2006).

According to Sęk (2005), in functional terms, social support is defined as a type of social interaction undertaken by one or two parties who participate in a problematic, difficult, stressful or critical situation, and that in the course of this interaction, emotions, information, instruments, activities and material goods are exchanged. This exchange can be unilateral or bilateral, and the donorrecipient direction can be constant but may also change. In this dynamic system of interactions, one can distinguish those seeking support and those supporting, that is those receiving or providing support. For the effectiveness of this social exchange, it is important to adjust the type of support provided to the recipient's needs. In turn, the goal of a supportive interaction is to sustain and reduce a crisis or stress level by accompanying the person, exchanging emotions, creating a sense of belonging, security and hope, and moving closer to solving the problem and overcoming difficulties.

On the other hand, social support in structural terms is defined as "objectively existing and accessible social networks, which stand out from other networks due to the fact that through the existence of bonds, social contacts and affiliation, they play a helpful role towards people in a difficult situation. [...] potentially and extremely helpful functions, i.e. they work for the benefit of their members or people for whom this network is available" (Sęk, Cieślak, 2006). In this understanding of support, important concepts include support networks, also known as sources of social support.

Two types of sources of support can be distinguished:

- natural sources of support, in the form of significant persons, spouses, family and friends; these are the most beneficial for the supported person and are related to trust in the support partners;

- formalized sources of support in the form of associations and support groups that have a specific way of operating, are less spontaneous and give a lower sense of intimacy (Heszen, Sęk, 2007).

Social support can be defined as a type of interaction characterized by:

- aiming to bring participants closer to overcoming difficulties, solving problems, reorganizing a disrupted relationship with those in the environment, and emotional support; 
- an exchange in the course of interaction of emotions, information, instruments of action and material goods;

- the fact that for this social interaction to be effective, the relevance between the expected and received support is important;

- exchanges in the course of this interaction being reciprocal or unilateral, while the direction of the supportive - supported relationship may be constant or variable;

- interaction and exchange being undertaken in a difficult and problematic situation (Sęk, 1993).

Another division of social support, which assumes the features of structural support, distinguishes:

- perceived support, which results from the beliefs of a person and their knowledge of from whom and where they can receive help in difficult situations, and the availability of a support network;

- received (granted) support, which is objectively assessed by the recipient as the type and amount of support actually received (Sęk, 2001; Cieślak, Eliasz, 2006).

First and foremost, social support is a resource that protects an individual from stress and increases their effectiveness in coping with it. For the purposes of this paper, the structural definition of social support was adopted.

\section{RESEARCH PROBLEM AND AIMS}

In terms of the theoretical analysis, the aim of the research was to determine social support in the perception of mothers of children with autism spectrum disorders who experience their husbands' economic migration. An important goal was also to show the differences between the perception of social support among mothers of children with autism spectrum disorders who experience their husbands' migration and those whose husbands do not go abroad for work.

The goals were specified in the form of a research question: What is the perception of social support among mothers of children with autism spectrum disorders who experience their husband's labour migration, and is this different from that of mothers of children with autism spectrum disorders whose husbands do not migrate?

In this paper, no research problem hypothesis was formulated as the problem raised is exploratory. 


\section{TEST METHOD AND SAMPLE CHARACTERISTICS}

The research used the diagnostic survey method, and employed the following tools: the Polish adaptation by Ewa Szlachta of the ISEL questionnaire (The Interpersonal Support Evaluation List), as well as a self-made questionnaire.

The first questionnaire is the Polish version of the commonly used ISEL questionnaire developed at the beginning of the 1980's in the USA. It is used for measuring perceived availability of four forms of social support (cognitive, tangible, boosting self-esteem, membership), which, according to the authors, play a significant role in coping with various stressful situations. It is composed of 40 statements describing social resources which form four scales. A respondent responds to all statements concerning his or her relations with important persons in his or her environment by marking the answers from 1 - completely irrelevant to 4 - completely accurate. A high value indicates high perceived social support. Results are calculated by summing up the points on a particular scale. In order to avoid any bias in the answers provided, half of the statements are formulated in a negative way and require re-encoding before the results are calculated. The result for the overall scale measures overall perceived social support and can range from 40 to 160 points. The questionnaire analyses 4 types of support $(10$ statements for each), and the results for each can range from 10 to 40 points:

- cognitive support (informative) - perceived availability of persons with whom an individual can talk about difficulties and problems, which favours a better understanding of one's own situation;

- tangible (substantive) - perceived availability of specific support (tangible, financial, provision of shelter, etc.);

- boosting self-esteem - perceived availability of positive comparison with other persons, offering a person the feeling of being accepted, valued and admired by other people;

- membership - perceived availability of persons with whom an individual can spend time and act together.

The reliability of the scale calculated for the Polish version is high. Cronbach's alpha for internal consistency for the overall scale is 0.90 , while for the sub-scales it ranges from 0.69 to 0.79 . The reproducibility of the results, measured by the test-retest method, is satisfactory as the correlation factors are high and statistically significant. The accuracy of the questionnaire was acknowledged by factor analysis, which revealed significant correlations between the ISEL scales and other questionnaires measuring social support (Szlachta, 2009).

The theoretical basis of the questionnaire is based on the social support buffer concept, according to which the perception of the availability of support from the 
environment is a buffer mitigating the effects of stress. The tool is used for both individual and group measurement. When providing answers, no additional skills are required from the respondent, and the average time needed to respond to all the statements is 15 minutes (Szlachta, 2009).

The self-constructed questionnaire includes semi-open and closed questions, and consists of three parts. The first part contains data on the child's parents, namely their age, education, employment, migration duration and the husband's place of migration. The second part concerns material status. It includes questions about the place of residence and financial situation. The third part concerns the structure of the family and also includes questions about the disabled child, their age and any additional disorders.

The survey questionnaire prepared for selection of the comparative group was constructed analogically, with only the questions about the place and duration of migration being omitted.

The research was conducted in 2019 at the Specialist Outpatient Clinic for People with Autism in Leżajsk. Intentional sampling was used. The study involved 46 mothers raising children with autism spectrum disorders who experience their husbands' migration, and 48 mothers raising children with autism spectrum disorders who do not experience their husbands' migration.

The selection criteria for the primary group (A) were:

- raising a child with autism spectrum disorders; husband's foreign migration,

- age of children with autism ranging from 3 to 9 years (preschool, school).

The comparative group consisted of mothers raising children with autism spectrum disorders who do not experience their husband's migration (B). The criterion for selecting this group was: maximum approximation of all demographic and social indicators to the indicators defining the primary group, in particular: age of children with autism spectrum disorders ranging from 3 to 9 years (preschool, school).

Data analysis shows that the mean age of the surveyed mothers in group A was 33 years old (from 18 to 49), and in group B was 37 years old. The level of education of the women in group A was: secondary (38\%), vocational (32\%) and higher (30\%); while in group B it was secondary (42\%), vocational (31\%) and higher (27\%). Of the participants in the group A, 53\% lived in the city and $47 \%$ in rural settings, while in group B 52\% lived in rural settings and $48 \%$ in the city. Most mothers in group A lived in their own apartment (59\%), with $41 \%$ living with their parents, while most mothers in group B lived with their parents (63\%), with $37 \%$ living in their own apartment. Among the surveyed mothers in group A, not all had employment, with only $34 \%$ of women in work. Similarly, only $37 \%$ of women in group B were in employment. 
The economic situation of $63 \%$ of mothers of children with autism spectrum disorders whose husbands migrate was good, for about $27 \%$ it was average, and for only $10 \%$ it was bad. The surveyed women positively assessed the financial situation in their homes as this was related to the higher earnings that their husband received abroad. Mothers of children with autism spectrum disorders whose husbands do not migrate rated their economic situation as average $56 \%$, with approximately $24 \%$ rating it as good and $20 \%$ as bad.

The women most often experience long-term migration of their husbands, lasting from 6 to 12 months (55\%), followed by short-term departures lasting from 3 to 6 months (45\%). Women had not experienced trips lasting more than a year.

The women's partners most often migrated to Great Britain (70\%), Norway (15\%), France (8\%) and Germany (7\%).

All the surveyed mothers in group B had full families. In all families, both in the primary and comparative groups, there was one child with a disability.

In the studied families in group $\mathrm{A}$, the age of the children with autism spectrum disorders was: 3 years (7\%), 5 years (13\%), 6 years (15\%), 8 years (45\%) and 9 years (20\%).

In the studied families in group $B$ the age of the children with autism spectrum disorders was: 3 years (11\%), 4 years ( $9 \%), 5$ years $(5 \%), 6$ years $(22 \%), 8$ years $(48 \%)$ and 9 years $(5 \%)$.

Both the primary and comparative children had been diagnosed with autism. There were 9 children in the primary group with multiple disabilities (autism spectrum disorder and intellectual disability). The comparison group included 11 children with multiple disabilities (autism spectrum disorder and intellectual disability). Among the additional disorders in the children with autism spectrum disorders, 5 children with allergies were found in group A, and 4 children with epilepsy and 1 with allergies in group B.

The mothers studied in both groups were participants of support groups for parents as part of a program offered at the clinic for people with autism.

\section{DATA ANALYSIS PROCEDURE}

A comparative analysis of the results obtained from the subjects in both groups was carried out using the non-parametric Mann-Whitney $U$ test. The selection of the significance test was dictated by the following conditions:

- type of data (qualitative and quantitative),

- measurement scale of the independent variable,

- normal distribution of the independent variable, 
- the assumption of homogeneity of the variance of the independent variable was met (Brzeziński, 2007).

The assumptions of the normality of the distribution of variables were checked using the Shapiro-Wilk test, which is used in the case of groups of less than 100 people. All calculations were performed using Statistica 13 software.

\section{RESULTS}

Analysis of social support in the perception of mothers of children with autism spectrum disorders.

Below, an analysis of social support is made that takes into account the following scales: cognitive support, material support, appreciation, belonging and a general scale.

For this purpose, mean values were calculated for mothers bringing up children with autism spectrum disorders who experience their husband's migration (primary group A), and for mothers raising children with autism spectrum disorders who do not experience their husband's migration (comparative group B).

The significance of differences test (Mann-Whitney U test) was also calculated. The results of the analyses are presented in Table 1.

Table 1.

Social support perceived by the mothers studied

\begin{tabular}{|c|c|c|c|c|c|c|c|}
\hline \multirow{2}{*}{ Scales } & \multicolumn{2}{|c|}{ Group A } & \multicolumn{2}{|c|}{ Group B } & \multirow[b]{2}{*}{$\mathbf{X}_{1}-\mathbf{X}_{2}$} & \multirow[b]{2}{*}{$Z$} & \multirow[b]{2}{*}{$p$} \\
\hline & $\mathrm{X}_{1}$ & $S_{1}$ & $\mathrm{X}_{2}$ & $S_{2}$ & & & \\
\hline Cognitive Support & 27.01 & 3.54 & 31.04 & 5.03 & -4.03 & 5.246 & 0.000 \\
\hline Material support & 33.08 & 4.54 & 31.05 & 3.38 & 2.03 & 2.189 & 0.028 \\
\hline Valuation & 25.19 & 3.42 & 30.67 & 4.48 & -5.48 & 5.954 & 0.000 \\
\hline Membership & 26.04 & 2.44 & 27.45 & 3.37 & -1.41 & 1.936 & 0.047 \\
\hline Overall result & 111.32 & 13.94 & 120.21 & 16.26 & -8.89 & 4.399 & 0.000 \\
\hline
\end{tabular}

Source: own study.

The surveyed mothers of children with autism spectrum disorders experiencing their husband's migration most often perceived the material support they received, as evidenced by the result obtained from them $(\mathrm{X} 1=33.08)$. The material support scale consists of statements which indicate that people with high scores perceived the help they receive in the event of financial problems when they need assistance, e.g. fees related to education, therapy or treatment of a child with autism spectrum 
disorders. The lowest results were obtained from mothers in this group on the appreciation scale $(\mathrm{X} 1=25.19)$. The low results obtained on this scale prove that the respondents cannot identify people with whom they have close relationships, who are proud of them, value them and for whom they are important and whom they can equal in everything.

Mothers of children with autism spectrum disorders who do not experience their husband's migration, also perceive the material support provided to them the most among the surveyed types of social support, and on this scale the respondents obtained the highest average score $(\mathrm{X} 2=31.05)$. These mothers, similarly to the subjects from the primary group, obtained the lowest results on the belonging scale $(\mathrm{X} 2=27.45)$.

After conducting analysis of the results obtained from mothers of children with autism spectrum disorders who experience their husband's migration and those who do not experience migration, it can be concluded that the surveyed women whose husbands do not migrate more often perceive all types of support given to them than women from the primary group, apart from material support, which in the primary group is higher. Mothers of children with autism spectrum disorders experiencing their husbands' migration obtained significantly lower scores on all scales except for the material support scale. The subjects differ the most in terms of cognitive support $(\mathrm{X} 1=27.01 ; \mathrm{X} 2=31.04)$, and this difference is statistically significant, $p<0.001$. Obtaining lower results on the scale of cognitive support means that the respondents do not perceive kind people around them to whom they can turn for help and advice in solving problems and with whom they can share their most personal information. Perhaps the lack of a close person (a husband) also affects their relationships with other close people and limits the number of contacts they have. This type of support is also important as it provides feedback on the effectiveness of one's own actions.

There were also statistically significant differences between the results of the surveyed mothers on the material support scale $(p<0.05)$ and in the overall result $(p<0.001)$.

\section{DISCUSSION OF THE RESULTS}

The obtained results were compared with standardization studies using the Polish version of the ISEL questionnaire completed by 154 healthy adults (male and female). The mean values are: on the general scale - 128.80, on the cognitive support scale -32.89 , on the material support scale - 33.44, on the appreciation scale - 30.05, and on the belonging scale - 32.42 (Szlachta, 2009). 
The results on the general scale obtained from mothers of children with autism spectrum disorders experiencing their husband's migration $(\mathrm{X} 1=111.32)$ are significantly lower than the mean values from Polish normalization studies, while the result of women from the comparative group is slightly lower $(\mathrm{X} 1=120,21)$.

In the individual types of perceived social support on the ISEL scale, mothers from the primary group had significantly lower results than the average values obtained by respondents in standardization studies, except for the material support scale, where the results are similar. On the other hand, the results of mothers of children with autism spectrum disorders who did not experience their husband's migration showed that they obtained lower results on the membership scale, while on the other scales their results were similar to the mean values obtained by respondents in the normalization studies mentioned above.

Summing up, the results of women from the primary group on all scales were significantly lower than the results of people from the standardization studies, except for the material support scale where the results are similar. This proves that the surveyed mothers of children with autism spectrum disorders who experience their husband's migration are aware of the fact that they do not receive sufficient social support in various areas. This is limiting for them as they do not have a group of friends that they can count on and who will help them, thus making them better able to cope with the problems related to raising a child with a disability. It would seem to be important to have a husband as the closest person to them with whom they could share their concerns about everyday problems.

Social support in various forms is especially needed by mothers of children with autism spectrum disorders whose husbands migrate for work because they are deprived of the presence and support of a partner in caring for a disabled child.

The results obtained above indicate that the social support obtained by mothers of children with autism spectrum disorders whose husband migrates is insufficient.

\section{CONCLUSIONS}

The obtained research results indicate the need for preventive action. On the basis of the obtained results, it can be noticed that mothers of children with autism spectrum disorders experiencing their husband's foreign migration need support mainly from their relatives. Actions supporting and compensating the separation of the spouses should be taken at the time of the decision to go abroad. The diagnosis should focus not only on the difficulties, but above all, it is necessary to indicate what resources the spouses have that will enable them to cope with the temporary separation. The personal resource that is social support contributes to reducing 
the negative effects of stress. Support provided by existing, diverse social ties provides a sense of understanding from other people. Contact with other people, especially the husband and family, gives the individual a sense of belonging and closeness. They therefore open up to ever wider social contacts who teach them how to deal with various problems in life.

In addition, a family raising a disabled child with the added problem of a father's migration should be included in activities aimed at:

- diagnosing changes in the functioning of the family as soon as possible;

- providing psychological help;

- providing access to support groups;

- informing family members about the threats to family life connected with migration (e.g. special guides, TV programs);

- providing assistance and support in the re-emigration of men, including career counselling, job placement and flexible forms of employment.

The conducted study does not allow for an in-depth analysis of the social support for mothers raising children with autism spectrum disorders who experience their husband's migration.

\section{RESEARCH LIMITATIONS}

The presented results serve only as an attempt to answer the question posed, and provide only a limited range of knowledge. In the future, it would be worth looking at the factors that influence the level of this variable.

\section{REFERENCES}

Baker-Ericzen, M.J., Brookman-Frazee, L., Stahmer, L. (2005). Stress levels and adaptability in parents of toddlers with and without autism spectrum disorders. Research \& Practice for Persons with Severe Disabilities, 30(4), 194-204. DOI: 10.2511/ rpsd.30.4.194

Bitsika, V., Sharpley, C., Bell, R. (2013). The buffering effect of resilience upon stress, anxiety and depression in parents of a child with an autism spectrum disorder. Journal of Developmental and Physical Disabilities, 25(5), 533-543. DOI: 10.1007/ s10882-013-9333-5

Boyd, B.A. (2002). Examining the relationship between stress andlack of social support in mothers of children with autism. Focuson Autism and Other Developmental Disabilities, 17, 208-215. DOI: 10.1177/10883576020170040301 
Breitkreuz, R., Wunderli L., Savage, A., McConnell, D. (2014). Rethinking resilience in families of children with disabilities: A socioecological approach. Community, Work \& Family, 17, 346-365. DOI: 10.1080/13668803.2014.893228

Brzeziński, J. (2007). Metodologia badań psychologicznych. Warszawa: PWN.

Caarls, K., Mazzucato, V. (2015). Does international migration lead to divorce? Ghanaian Couples in Ghana and Abroad In Population, 70, 127-151.

Chodkowska, M. (2007). Socjopedagogiczne aspekty współpracy pedagoga specjalnego $\mathrm{z}$ rodzicami dziecka niepełnosprawnego. Szkoła Specjalna, 1, 3-8.

Cieślak, R., Eliasz, A. (2006). Wsparcie społeczne a osobowość. W: H. Sęk. R. Cieślak (red.). Wsparcie społeczne, stres i zdrowie (s. 49-67). Warszawa: PWN.

Dabrowska, A., Pisula, E. (2010). Parenting stress and coping styles in mothers and fathers of pre-school children with autism and Down syndrome. Journal of Intellectual Disability Research, 54(3), 266-280. DOI: 10.1111/j.1365-2788.2010.01258.x

Farrugia, D. (2009). Exploring stigma: medical knowledge and the stigmatisation of parents of children diagnosed with autism spectrum disorder. Sociology of Health \& Illness, 31, 1011-1027.

Feldman, M., McDonald, L., Serbin, L., Stack, D., Secco, M.L., Yu, C.T. (2007). Predictors of depressive symptoms in primary caregivers of young children with or at risk for developmental delay. Journal of Intellectual Disability Research, 51, 606-619. DOI: 10.1111/j.1365-2788.2006.00941.x

Fojcik, M. (2007). Dziecko a migracja zarobkowa rodziców. Życie Szkoły, 7, 12-15.

Gagat-Matuła, A. (2018). Poczucie koherencji matek dzieci z autyzmem doświadczających migracji męża. Pedagogika Rodziny, 8, 113-123.

Kirenko, J., Byra, S. (2008). Zasoby osobiste w chorobach psychosomatycznych. Lublin: Wyd. UMCS.

Luther, H.D., Canham, L.D., Cureton, Y.V. (2005). Coping and social support for parents of children with autism. Journal of School Nursing, 21, 40-47. DOI: 10.1622/1059-8405(2005)021[0040:cassfp]2.0.co;2

Padden, C., James, J.E. (2017). Stress among parents of children with and without autism spectrum disorders: a comparison involving physiological indicators and parent self-reports. Journal of Developmental and Physical Disabilities, 29, 567-586. DOI: $10.1007 / \mathrm{s} 10882-017-9547-\mathrm{Z}$

Pisula, E. (1998). Psychologiczne problemy rodziców dzieci z zaburzeniami rozwoju. Warszawa: Wyd. UW.

Sekułowicz, M. (2013). Wypalanie się sił rodziców dzieci z niepełnosprawnością. Wrocław: Wyd. Naukowe Dolnośląskiej Szkoły Wyższej.

Sęk, H. (1997). Rola wsparcia społecznego w sytuacji kryzysowej. W: D. Kubacka-Jasiecka. A. Lipowska-Teutsch (red.). Oblicza kryzysu psychologicznego i pracy interwencyjnej (s. 159-169). Kraków: ALL. 
Sęk, H. (2001). O wieloznacznych funkcjach wsparcia społecznego. W: L. Cierpiałkowska. H. Sęk (red.). Psychologia kliniczna i psychologia zdrowia (s. 13-33). Poznań: Humaniora.

Sęk, H. (2005). Rola wsparcia społecznego w sytuacji kryzysu. W: D. Kubacka-Jasiecka. T.M. Ostrowski (red.). Psychologiczny wymiar zdrowia, kryzysu, choroby (s. 143-158). Kraków: Wyd. UJ.

Sęk, H. (2006). Rola wsparcia społecznego w sytuacjach stresu życiowego. O dopasowaniu wsparcia do wydarzeń stresowych. W: H. Sęk. R. Cieślak (red.). Wsparcie społeczne, stres izdrowie (s. 49-67). Warszawa: PWN.

Sęk, H., Cieślak, R. (2006). Wsparcie społeczne - sposoby definiowania, rodzaje i źródła wsparcia, wybrane koncepcje teoretyczne. W: H. Sęk. R. Cieślak (red.). Wsparcie społeczne, stres i zdrowie (s. 11-28). Warszawa: PWN.

Shobana, M., Saravanan, C. (2014). Comparative study on attitudes and psychological problems of mothers towards their children with developmental disability. East Asian Archives of Psychiatry, 24, 16-22.

Szlachta, E. (2009). Próba adaptacji i walidacji polskiej wersji The Interpersonal Support Evaluation List (ISEL) - Kwestionariusz Spostrzeganego Wsparcia Społecznego. Przeglad Psychologiczny, 52, 433-451.

Szymborski, J., Potrykowska, A. (2009). Migracje zagraniczne a polityka rodzina. Warszawa: Biuletyn RPO.

Tøssebro, J. Wendelborg, Ch. (2015). "Ordinary or not? Families of children growing up with disabilities". In Childhood and disability in the Nordic countries: Being, becoming, belonging. edit. R. Traustadóttir, B. Ytterhus, S.T. Egilson and B. Berg. Basingstoke: Palgrave (p. 199), DOI: 10.1057/9781137032645_13

UNICEF [United Nations Children's Found] (2020). Children "Left Behind", UNICEF Working Paper. Pobrane z: https://www.unicef.org/media/61041 [dostęp: 10.11.2020].

\section{WSPARCIE SPOŁECZNE W PERCEPCJI MATEK DZIECI Z ZABURZENIAMI ZE SPEKTRUM AUTYZMU DOŚWIADCZAJĄCYCH MIGRACJI MĘŻA}

Streszczenie: Wprowadzenie: Matki dzieci z zaburzeniami ze spektrum autyzmu, których mąż wyjeżdża w celach zarobkowych za granicę, są przeciążone codziennymi zmaganiami związanymi z wychowaniem dziecka. Stąd tak istotne jest wsparcie społeczne, jakie mogą otrzymać w sytuacji doświadczania permanentnego stresu, a taką sytuacją jest wychowanie dziecka z niepełnosprawnością i migracja zagraniczna męża. Cel badań: Celem pracy było określenie wsparcia społecznego w percepcji matek dzieci z zaburzeniami ze spektrum autyzmu, które doświadczają migracji zarobkowej męża. Ważnym celem było także ukazanie różnic w zakresie postrzeganego wsparcia społecznego u matek dzieci z zaburzeniami ze 
spektrum autyzmu, które doświadczają migracji męża i tych, których mąż nie migruje. Metoda badań: W badaniach wykorzystano metodę sondażu diagnostycznego. Posłużono się następującymi narzędziami: Kwestionariuszem ISEL w polskiej adaptacji Ewy Szlachty, a także kwestionariuszem własnej konstrukcji. W badaniach wzięły udział 94 matki wychowujące dzieci z zaburzeniami ze spektrum autyzmu: 46 kobiet, których mąż migruje (A) oraz 48 kobiet, które nie doświadczają migracji męża (B). Dobór próby był celowy. Wyniki: Analiza danych dotyczących postrzeganego wsparcia społecznego wykazała różnice istotne statystycznie w badanych grupach w wyniku ogólnym i we wszystkich skalach. Wyniki wskazują, że matki dzieci z zaburzeniami ze spektrum autyzmu, których mąż wyjeżdża za granicę, choć posiadają lepszą sytuację finansową, to brak obecności, aktywnego udziału i wsparcia męża w opiece nad dzieckiem sprawia, że odczuwają mniej wsparcia społecznego (skala wsparcie poznawcze, przynależność, dowartościowanie), znacznie gorzej radzą sobie z problemami niż kobiety, których mąż nie migruje. Wnioski: Wyniki badań wskazują na potrzebę oddziaływań profilaktycznych.

Słowa kluczowe: matka, migracja, spektrum zaburzeń autyzmu, wsparcie społeczne 